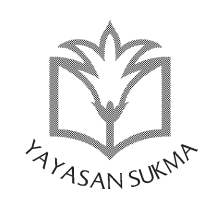

SUKMA: JURNAL PENDIDIKAN

ISSN: 2548-5105 (p), 2597-9590 (e)

Volume 3 Issue 1, Jan-Jun 2019, pp. 93-116

https://doi.org/10.32533/03105.2019

www.jurnalsukma.org

\title{
POTRET PENDIDIKAN DI ERA GLOBALISASI Teknosentrisme dan Proses Dehumanisasi
}

\section{Eva Dewi}

Institut Agama Islam Negeri (IAIN) Bengkulu, Indonesia email: evadewi1975@yahoo.co.id

\begin{abstract}
Abstrak
Pendidikan merupakan unsur yang paling penting bagi kemajuan peradaban bangsa. Era Industri dan globalisasi membawa dampak terhadap proses pendidikan terutama di Indonesia. Di satu sisi, globalisasi memberi dampak positif, namun di sisi lain, dominasi teknologi membawa dampak negatif, yakni menimbulkan dehumanisasi dalam bentuk mentalitas yang terlalu mengagungkan teknologi di atas segalanya. Realitasnya, pendidikan di era globalisasi saat ini mengalami krisis nilai. Pendidikan hanya menghasilkan outputoutputyang pintar secara kognitif, menguasai teori dan teknologi tetapi kering dari nilai-nilai kemanusiaan dan sosial (dehumanisasi). Sebagai solusinya, pendidik-
\end{abstract}


an sebagai investasi haruslah mampu "memanusiakan manusia"; mengintegrasikan human being dan technobeing atau keterpaduan sains dan agama, dan reparadigmatisasi pendidikan dengan value approach, social cultural approach, cognitif skill approach dan political policy approach tentu saja sangat dibutuhkan untuk mencapai tujuan pendidikan nasional dalam rangka membentuk generasi profesional, bermoral, bertanggung jawab dan bermartabat.

Kata Kunci: pendidikan, globalisasi, teknosentrisme, dehumanisasi.

\section{A. Pendahuluan}

Globalisasi telah menjadi kekuatan besar yang membutuhkan respon tepat karena ia memaksa suatu strategi bertahan hidup (survival strategy) dan strategi pengumpulan kekayaan (accumulative strategy) bagi berbagai kelompok dan masyarakat. proses ini telah membawa "pasar" menjadi kekuatan dominan dalam pembentukan nilai dan tatanan sosial yang bertumpu pada prinsip-prinsip komunikasi padat dan canggih. Pasar telah pula memperluas orientasi masyarakat dan mobilitas batas-batas sosial budaya. Pasar sekaligus mengaburkan batas-batas itu akibat berubahnya orientasi ruang dalam masyarakat (Abdullah 2010, 165).

Posisi mesin dan teknologi menjadi semakin penting dari waktu ke waktu yang cara kerjanya dan nilai-nilai yang melekat sangat mempengaruhi ritme kehidupan dan norma-norma yang terbentuk. Proses dehumanisasi yang telah menjadi suatu mode pembicaraan tentang dampak teknologi pada tahun 1980-an, telah melahirkan apa yang disebut Foucault sebagai "the death of the subject". Proses ini menentukan bagaimana struktur hubungan antar orang diberi makna; kehadiran berbagai electronic space seperti handphone, ATM, nintendo, komputer dan internet telah mengurangi hubungan hubungan face-to-face secara substansial 
(Abdullah 2010, 20).

Munculnya "ruang elektronik" dalam proses kehidupan secara meluas menyebabkan hilangnya proses "social learning" yang memungkinkan empati dilakukan dalam hubungan antar manusia. Batas-batas sosial yang semakin tegas, kemudian membutuhkan sistem ideologi yang lebih kuat selain untuk mempengaruhi proses "social learning" juga untuk mengikat kelompok yang semakin kentara batas dan keberadaannya. Untuk itu "strong state" sangat dibutuhkan pada abad mendatang tidak untuk melicinkan pasar global, tetapi untuk menyelamatkan ruang-ruang publik yang memungkinkan masyarakat mengembangkan identitas dan jati dirinya sebagai orang Indonesia (Abdullah 2010, 39). Ruang-ruang sosial semakin sempit sejalan dengan dibentuknya berbagai ruang elektronik (electronic space) yang lebih efisien. Individu disini semakin terpisah dari kelompok sosialnya yang menyebabkan nilai dan pemaknaan menjadi bersifat relatif dan terdiferensiasi. Hubungan personal menjadi kurang penting sejalan dengan menghilangnya empati emosional dalam diri individu-individu (Abdullah 2010, 168).

Strategi yang utama untuk membangun bangsa bermartabat adalah melalui pendidikan. Untuk mencapai hal itu, diperlukan pembentukan pandangan hidup yang masyarakat yang dapat mengarahkannya menjadi bangsa yang bermartabat. Selain itu, lembaga pendidikan juga merupakan proses pembentukan manusia yang cerdas, bermoral, memiliki motivasi hidup dan semangat mengembangkan ilmu dan teknologi (Indra 2005, 189). Sesuai dengan UU No. 20 tahun 2003 tentang Sistem Pendidikan Nasional, Pasal 3, Tujuan pendidikan Nasional adalah "Mengembangkan potensi Peserta didik agar menjadi manusia yang beriman dan bertakwa kepada Tuhan Yang Maha Esa, berakhlak mulia, sehat, berilmu, cakap kreatif, mandiri dan menjadi warga negara yang demokratis serta bertanggung jawab." Pendidikan yang memanusiakan manusia adalah sebuah keharusan karena ia menjadi pilar dasar bagi keberhasilan pendidikan sebagai bagian yang penting untuk mencerdaskan kehidupan bangsa. M. Sastrapratedja menawarkan pendidikan berwawasan kemanu- 
siaan itu ada tiga kekuatan dalam diri peserta didik yang harus ditumbuhkan: (1) daya untuk berbuat (power to); (2) solidaritas dan kekuatan bersama untuk memecahkan permasalahan yang dihadapi dan untuk kesejahteraan bersama (power with); dan (3) kekuatan spritual dan nilai-nilai yang ada dalam diri anak agar lebih manusiawi (bermartabat) (power within) (Yamin 2009, 222).

Realitasnya, pendidikan dewasa ini mengalami krisis nilai. Pendidikan hanya menghasilkan output-output atau lulusan yang pintar secara kognitif, banyak menguasai teori dan teknologi, tetapi kering dari nilai-nilai kemanusiaan dan sosial dalam penerapannya. Pertanyaan yang sering muncul adalah bagaimana anak bisa mencapai nilai yang tinggi, artinya keberhasilan seorang anak hanya diukur dengan angka atau nilai raport, menguasai teknologi, cepat mencapai gelar Sarjana, Master, Doktor atau Profesor, setelah lulus dari instansi pendidikan akan kerja di mana, dan sebagainya. Nilai-nilai humanistik, jujur, disiplin, tanggung jawab terabaikan dan kurang mendapat perhatian utama baik dari lembaga pendidikan maupun masyarakat.

Para peneliti telah mengeksplorasi "marketisasi" pendidikan ini, fokus bagaimana restrukturisasi ekonomi dimanifestasikan dalam pendidikan terkait dengan penciptaan pasar baru untuk investasi modal dan penjaminan penjualan massal teknologi informasi dan komunikasi baru. Para pendidik mengajukan kritik ideologis terhadap praktik ini karena telah melanggar nilai-nilai pendidikan dan pekerjaan pendidik dianggap bisnis (Apple and Singh 2005, 14). Menariknya, pemerataan akses pendidikan hanya sebuah mitos dan tidak bisa dinikmati oleh seluruh anak bangsa. Kenyataannya yang terjadi pada anak-anak miskin tetap mengalami kesulitan untuk menikmati pendidikan walaupun berprestasi. Teriakan mahasiswa, "Hancurkan kapitalisme pendidikan"!, "Realisasikan pendidikan gratis"! dalam berbagai berbagai demonstrasi, karena biaya pendidikan yang semakin lama semakin tidak rasional. Janji politik untuk membuka akses pendidikan secara merata tidak terealisasi (Yamin 2009, 133). 
Tambah lagi, lunturnya nilai-nilai moral dalam kultur masyarakat dalam bentuk-bentuk aksi negatif seperti maraknya mentalitas korupsi dengan berbagai bentuknya, penyalah-gunaan kekuasaan, lunturnya solidaritas sosial, meningkatnya semangat primordialisme yang mendasarkan diri pada suku, etnis, maupun paham agama dapat mengakibatkan konflik dan keutuhan bangsa semakin terancam. Oleh karena itu, meskipun ilmu pengetahuan dan teknologi semakin meningkat, namun angka kriminalitas yang juga terus meningkat telah menyulitkan pengembangan sistem pendidikan yang mampu mengembangkan nilai-nilau sosial dan humanisme bagi setiap individu (Koesoema 2007, 224).

Berdasarkan fenomena tersebut, terlihat potret atau gambaran pendidikan di era industri dan globalisasi ini, keberhasilan manusia diatur dan diukur oleh mesin, teknologi, dan mengabaikan kecerdasan humanis yang sebenarnya harus diprioritaskan diatas pengetahuan lainnya. Dampak dari hal ini akan melahirkan individu-individu yang memiliki orientasi hidup hedonis, materialistis dan memiliki kepribadian yang terbelah (split personality). Untuk menjawab permasalahan tersebut, penulis menggunakan pendekatan fenomenologis, yaitu pendekatan tradisi fenomenologi yang memusatkan perhatian pada pengalaman hidup dan mencari makna mengenai realitas berdasarkan sudut pandang subjek penelitian. Brouwer mengatakan bahwa seorang fenomenolog senang melihat gejala atau fenomena. Fenomenologi bukan suatu ilmu. Tidak ada sistem, tidak ada hipotesa, tidak ada teori. Akan tetapi fenomenologi adalah suatu metode pemikiran, a way of looking at things. Fenomenologi adalah subjek dan objek menjadi satu secara dialektis (Brouweir 1984, 3-5). Kajian ini menjadi sangat urgen untuk dilakukan sebagai upaya mencoba untuk menjawab permasalahan dehumanisasi pendidikan di era globalisasi dengan menawarkan upaya-upaya yang harus dilakukan oleh lembaga pendidikan untuk melahirkan manusia yang berkualitas, profesional, bermoral, bertanggungjawab dan bermartabat. 


\section{B. Globalisasi dan Paradigma Pendidikan}

Globalisasi berasal dari bahasa Inggris "the globe" atau bahasa Prancis "La monde", yang berarti bumi atau dunia. Maka "globalisasi" atau "mondialisation" adalah proses menjadikan semuanya satu bumi atau satu dunia. Baylis dan Smith mendefinisikan globalisasi sebagai suatu proses meningkatnya keterkaitan antara masyarakat, sehingga peristiwa yang terjadi di wilayah tertentu berpengaruh pada kehidupan manusia atau masyarakat di wilayah lain. Anthony Gidens menyebut globalisasi sebagai "time space distanciation", yaitu dunia tanpa batas; ruang dan waktu bukanlah kendala yang berarti dalam kondisi seperti ini.

Dalam aspek lain, Wallerstain, seorang pelopor teori sistem dunia memandang globalisasi tidak sebatas hubungan lintas batas negara, namun globalisasi merupakan wujud kejayaan ekonomi kapitalis dunia yang digerakkan oleh logika akumulasi kapital. Sesuai dengan wallerstain, Jin Young Chung, ilmuwan politik asal Korea mendefinisikan globalisasi sebagai suatu proses integrasi dunia melalui peningkatan arus kapital, hasil-hasil produksi, jasa, ide dan manusia yang lintas batas negara (Machali, 2004, 109). Jadi, globalisasi merupakan pertemuan dua proses historis yang saling terkait, yakni: pertama, globalisasi merupakan produk dinamika ekspansi kapitalis dan akumulasi kapital (modal/ uang) yang tak terbatas. Kedua, globalisasi merupakan proyek yang dihasilkan atau sedang dilakukan oleh kekuatan-kekuatan sosial dominan yang tengah berusaha melembagakan kekuatannya dalam struktur historis yang akan membantu ekspansi transisional kapital di masa depan (Muslam 2011, 110).

Globalisasi tidak dapat dilepaskan dari revolusi industri yang terjadi di Eropa. Dalam perkembangannya, agenda globalisasi banyak dipegang oleh negara adidaya seperti Amerika Serikat. Negara adidaya tersebut berusaha mempengaruhi Dunia Ketiga, dengan paham neo-liberalisme ekonominya. Dari kecenderungan sistem ekonomi pasar bebas, akhirnya globalisasi merambah ke semua lini kehidupan, mulai dan sosial, budaya, politik, hukum sampai pendidikan tidak dapat dilepaskan dari pengaruh globa- 
lisasi (Muslam 2011, 127).

Dalam era global telah terjadi pergeseran paradigma dalam peradaban manusia menuju masyarakat berbasis pengetahuan (knowledge-based society). Pergeseran paradigma tersebut berimplikasi pada pergeseran paradigma pembangunan negara di dunia termasuk Indonesia. Pembangunan berbasis sumber daya alam menuju pembangunan berbasis sumber daya masyarakat berpengetahuan. Dalam kehidupan ekonomi, pergeseran paradigma tersebut memberikan implikasi terhadap terjadinya proses transisi perekonomian dunia yang semula berbasiskan pada sumber daya (resources based economy) menjadi perekonomian berbasis pengetahuan (knowledge based economy) (Solikhudin 2016, 404). Kekuatan global tersebut bertumpu pada empat hal, yaitu (1) kemajuan Ilmu pengetahuan dan teknologi, terutama dalam bidang informasi serta inovasi-inovasi baru dalam teknologi yang mempermudah kehidupan manusia, (2) perdagangan bebas yang ditunjang oleh ilmu pengetahuan dan teknologi, (3) kerjasama regional dan internasional antar bangsa tanpa mengenal batas negara, dan (4) meningkatnya kesadaran terhadap hak-hak asasi manusia dalam kehidupan bersama sekaligus meningkatnya kesadaran bersama dalam alam demokrasi (Istiarsono 2016, 20).

Di tengah kemajuan ilmu pengetahuan dan teknologi ini, di satu sisi kita lihat memiliki dampak positif bagi perkembangan dan kemajuan masyarakat agar lebih kreatif, inovatif, namun di sisi lain, kehidupan masyarakat dipenuhi nilai materialisme dan menolak realitas transendental. Masalah terbesar menurut al-Faruqi adalah pada bidang pendidikan (al-Faruqi 1988, 5). Kondisi pendidikan yang mengalami sekularisasi. Dikotomi pendidikan baik di tingkat level kurikulum makro maupun mikro. Pendidikan dalam arti luas adalah proses yang berkaitan dengan upaya untuk mengembangkan pada diri seseorang mengenai tiga aspek dalam kehidupannya, yakni, pandangan hidup, sikap hidup dan keterampilan hidup. Upaya untuk mengembangkan ketiga aspek tersebut bisa dilaksanakan di sekolah, luar sekolah dan keluarga (Muslam 2011, 3). 
Pendidikan menurut Mangun Wijaya, adalah proses awal usaha manusia untuk menumbuhkan kesadaran sosial pada setiap manusia sebagai pelaku sejarah. Sementara Jean Piaget mendefinisikan pendidikan sebagai penghubung dua sisi, yakni individu yang sedang tumbuh, dan di sisi lain, nilai sosial, intelektual dan moral yang menjadi tanggung jawab pendidikan terhadap individu. Begitu juga Ary H. Gunawan berpendapat bahwa pendidikan sebagai proses sosialisasi, yaitu sosialisasi nilai, pengetahuan, sikap dan keterampilan (Yamin 2009, 15-16).

Berdasarkan pengertian di atas, dapat kita pahami bahwa pendidikan bukan hanya mencetak masyarakat cerdas secara intektual saja dan tidak terdidik di lingkungan sekitar, akan tetapi seseorang dikatakan telah berpendidikan jika sudah mengalami perubahan pada aspek kognitif, afektif dan psikomotorik dan mampu berperan aktif melakukan perubahan yang baik dalam kehidupan sosial. Untuk mencapai tujuan pendidikan seperti ini, menurut Winarno Surachmad, seharusnya tekanan pendidikan tidak hanya pada aspek kognitif atau kemampuan berpikir saja, akan tetapi proses pendidikan juga harus mengutamakan watak, menghaluskan hati nurani, sehingga dapat ditumbuhkan kesadaran tentang kemampuan dan tidak kemampuan peserta didik (Suyanto and Abbas 2004, 32).

Namun, pada sisi lain, sekeras apapun upaya yang dilakukan oleh para guru di sekolah, hampir-hampir tidak membawa pengaruh pada peserta didik. Bahkan kita lihat semakin tinggi tingkat pendidikan perserta didik, semakin buruk sikap dan tingkah lakunya dan bukan sebaliknya. Hal ini terjadi karena tidak adanya sinergitas antara pendidikan di sekolah, masyarakat dan keluarga. Dan yang paling penting adalah pendidikan di keluarga adalah pendidikan yang paling utama dan pertama sekali anak peroleh dari kedua orang tua dan keluarga, dan anak lama tinggal di keluarga.

Louis V. Gestner Jr, dalam Reinventing Education (1995) mengemukakan tentang propil sekolah masa depan, ia mengisyaratkan orang tua dan masyarakat berperan serta dalam 
menunjang pendidikan. Sesuai paradigma otonomi sekolah yang diterapkan maka keikutsertaan orang tua dan masyarakat tersebut bukan hanya dalam hal pendanaan, pengelolaan dan mengevaluasi kinerja sekolah semata, akan tetapi bahkan tidak kalah pentingnya terjadi kinerja yang sinergis, terpadu dan selaras antara sekolah, orang tua dan masyarakat dalam hal menciptakan suasana yang kondusif sehingga mendorong siswanya untuk mampu bersaing secara sehat di era globalisasi ini (Suyanto and Abbas 2004, 34). H.A.R. Tilaar juga memperjelas bahwa kemerosotan akhlak dan moral merupakan masalah pendidikan sebagai akibat langsung dari perubahan hidup dari gaya hidup urban. Sekolah harus menanamkan nilai etika, moral dan akhlak setelah keluarga dan masyarakat (Suyanto and Abbas 2004, 35).

Kenyataannya, tingkat kesopanan siswa dinyatakan menurun, maka yang pertama-tama harus dilihat bagaimana intensitas, frekuensi dan kualitas komunikasi yang berlangsung antara orang tua dengan anak di rumah. Tingkat kesibukan orang tua bekerja dan penguasaan teknik komunikasi akan mengurangi intensitas bertemu dan komunikasi orang tua dengan anak. Diyakini bahwa semakin tinggi frekuensi komunikasi antara anak dengan orang tua, semakin besar pengaruh positifnya kepada anak, dan begitu juga sebaliknya. Problem kesantunan, kesopanan, moral dan akhlak anak lebih banyak terjadi di daerah perkotaan karena tingkat intensitas komunikasi orang tua dan anak lebih sedikit (Suyanto and Abbas 2004, 41).

Begitu juga lingkungan masyarakat tidak kalah pentingnya. Keteladanan masyarakat, kontrol sosial dan berbagai alat budaya dan alat komunikasi membawa pengaruh yang luar biasa pada seorang anak baik positif maupun negatif, apalagi di era keterbukaan informasi saat ini, maka pengetahuan agama adalah suatu kebutuhan dan keharusan sehingga anak mampu mengfilter pengaruh-pengaruh yang masuk (Suyanto and Abbas 2004, 44). Melihat problema tersebut, maka perlu adanya perubahan sosial yang cepat di atas menuntut adanya paradigma baru dunia pendidikan. Yakni adanya pandangan holistis. Pandangan ini berarti 
pendidikan akan menekankan pada pendekatan yang menyeluruh dan bersifat global. Pandangan holistis ini akan menimbulkan dua pembaharuan di dunia pendidikan, yakni pendidikan akan menekankan pada anak didik "berpikir secara global dan bertindak bersifat lokal", serta pembaharuan makna efisiensi, yakni tidak semata-mata bermakna ekonomis, tetapi meliputi pula keharmonisan dengan lingkungan, solidaritas dan kebaikan untuk semuanya (Muslam 2011, 7).

Pendidikan yang tengah berlangsung harus mampu mempersiapkan siswa minimal lima kompetensi yang dibutuhkan di era globalisasi ini, yaitu: (1) kompetensi intelektual yakni kemampuan berpikir dan bernalar, kreatif inovatif, kemampuan memecahkan masalah, dan kemampuan mengambil keputusan strategis. (2) kompetensi personal, yakni memiliki keluhuran jiwa dan moral yang baik, berupa kejujuran, disiplin, kemandirian, kritis dan bertanggung jawab, (3) kompetensi komunikatif, yakni memiliki kemampuan bahasa dan komunikasi dengan orang lain, (4) kompetensi sosial budaya, yakni kemampuan hidup bersama dan bekerjasama dengan orang lain, dan (5) kompetensi kinestesis vokasional, yakni kemampuan menggunakan ilmu pengetahuan dan teknologi untuk mendukung kemajuan kehidupan global (Istiarsono 2016, 3).

Sedangkan Boediono dalam Suyanto, mengatakan ada empat pendekatan yang bisa diterapkan dalam proses pendidikan pada masa global ini, yakni: (1) Cultural Transmission Approach; pendekatan ini menanamkan nilai-nilai budaya pada diri anak, sehingga mereka bisa mengetahui dan menghayati budaya bangsa sendiri; (2) Consideration Approach; pendekatan sebagai usaha untuk membangkitkan perhatian anak pada orang lain, seperti sifat empati dan kepekaan sosial terhadap kondisi orang lain yang di sekitarnya; (3) Values Clarification Approach; pendekatan sebagai usaha untuk menanamkan nilai-nilai positif pada diri anak, seperti kejujuran, disiplin, berakhlak mulia, bertanggung jawab terhadap keputusan dan tindakan yang diambilnya dan diyakininya bahwa itu benar; (4) Cognitive Development Approach; pendekatan ini menekankan pada pemikiran moral 
Potret Pendidikan di Era Globalisasi

(moral reasoning). Siswa mampu untuk membuat keputusan berdasarkan pertimbangan moral. Mereka akan mengembangkan tingkat yang lebih tinggi dalam pemikiran moral, yaitu takut hukuman, menaati peraturan dan berbuat untuk kebaikan orang banyak (Suyanto and Abbas 2004, 47).

\section{Teknosentrisme dan Dehumanisasi}

Teknosentrisme (technocentrism) adalah mentalitas teknologis yang mempercayai dengan berlebihan pada alat dan teknologi, seolah-olah segala sesuatu dapat diatasi dengan teknologi. Sentuhan tangan manusia dengan segenap perasaannya dianggap mempunyai nilai yang lebih rendah karena produknya tidak lebih baik, lama, dan tidak efisien (Jacob 1988, 71). Sedangkan dehumanisasi (dehumanization) adalah kemerosotan tata nilai. Kehilangan kepekaan kepada nilai-nilai luhur, seperti kebenaran, kebaikan, keindahan (estetik) dan kesucian. Mereka hanya peka dan menghargai nilai-nilai dasar, seperti materi (pemilikan kekayaan), hedonisme (kenikmatan jasmani), dan gengsi (prestise) (http://www.dictio.id).

Menurut Haslam (2006), dehumanisasi bisa dilihat di balik dimensi kemanusiaan, terdiri dari: pertama, "human uniqueness" (keunikan manusia), mengacu pada atribut yang membedakan manusia dari hewan lain, misalnya kesopanan, moralitas dan berpikir. Ketika atribut keunikan ini tidak ada pada manusia, maka secara eksplisit atau implisit, disamakan dengan hewan, seperti anak kecil, tidak dewasa, kasar, tidak rasional dan terbelakang. Kedua, "human nature" (sifat alami manusia), mengacu pada atribut kemanusiaan pada manusia, seperti emosi, kehangatan dan fleksibilitas. Ketika sifat-sifat alami manusia ini tidak ada, maka secara eksplisit atau implisit disamakan dengan benda atau mesin sebagai dingin, kaku, lembam dan tidak ada penghayatan (Bastian and Haslam 2011, 295).

Pengertian teknosentrisme dan dehumanisasi di atas sangat berhubungan. Ketika salah satu ciri sifat kemanusiaan, human nature hilang pada diri manusia, maka dampaknya sama 
$\overline{\text { dengan pandangan teknosentris, yang beranggapan mesin adalah }}$ segalanya. Semua ini terjadi karena pengaruh revolusi industri dan teknologi yang semakin masif dari waktu ke waktu. Revolusi industri dan teknologi tersebut telah mempengaruhi seluruh tatanan kehidupan manusia, termasuk pendidikan. Sungguh merupakan tantangan yang sangat besar bagi pendidikan akan datang. Pendidikan yang hanya didominasi pola pikir dan pandangan tekno sentris ansich, apalagi semua interaksi dalam proses pendidikan dimainkan oleh mesin dan manusia seperti robot, hal ini menimbulkan proses dehumanisasi dan nilai agama, moral dan budaya semakin lama semakin luntur pada diri pelaku pendidikan terutama peserta didik. Perlu keseimbangan dan keterpaduan pandangan dan pola pikir teknosentris dan humanis dalam proses pendidikan sekarang dan akan datang untuk mencapai tujuan pendidikan nasional yang ideal.

\section{Krisis Nilai dalam Pendidikan}

Globalisasi menurut Akhbar Ahmad dan Hasting adalah perkembangan yang cepat di dalam teknologi komunikasi, transformasi, jarak menjadi nisbi sehingga informasi dunia dapat dijangkau dengan mudah. Globalisasi merupakan kelanjutan dari modernisasi yang berisikan sekulerisasi yang misinya merupakan kelanjutan dari misi modern dan postmodernisme, yang semakin sekuler dan jauh dari agama. Dari sisi lain, globalisasi merupakan proses integrasi ekonomi nasional pada sistem perekonomian dunia berdasarkan keyakinan pada perdagangan bebas, yang sesungguhnya telah dicanangkan sejak zaman kolonialisme (Indra 2005, 59).

Globlisasi dan industri telah melahirkan masyarakat berstruktur industrial. Individu-individu dalam masyarakat dianggap sebagai bagian dari sistem produksi. Jacob menandai masyarakat industri ini dengan ciri-ciri: Pertama, mentalitas teknologis,yaitu suatu keadaan masyarakat yang memiliki kepercayaan yang berlebihan pada alat (teknosentris) seolah-olah segala sesuatu dapat dipecahkan dengan teknologi. Sesuatu akan lebih dipercaya bila 
dikerjakan dengan alat dan teknologi. Sentuhan tangan manusia dengan segenap perasaannya dianggap mempunyai nilai yang lebih rendah karena produknya tidak lebih baik, lama, dan tidak efisien. Pola pikir serba matematis-teknologis mengakibatkan terbentuknya pola pikir serba dikotomis. Jacob menyebutnya sebagai budaya terbelah yang merupakan pengaruh pemikiran Descartes dengan konsep rescogitans dan resextensa-nya, yang ada hanya benar atau salah, hitam atau putih, dan lain-lain. Kenyataan ini disadari atau tidak telah memunculkan masyarakat yang kaku dan tidak bijaksana. Mereka lupa bahwa di antara hitam dan putih ada warna lain, agak hitam, kelabu atau bahkan hitam sekali. Perlakuan pendidikan bercorak industrial ini telah membentuk manusia berperilaku seperti mesin karena di dalam pendidikan mereka dilatih dengan pola kerja mesin sehingga anak menjadi seperti komponen mesin industri.

Kedua, dampak adanya industri dalam pengajaran adalah munculnya diskriminasi ilmu. Masyarakat industri lebih respek terhadap ilmu eksakta dan keteknikan karena cara berpikirnya telah terpola karakter industri yang butuh kepastian (measurable) dan bukti nyata sebagaimana yang dibutuhkan para industrialis dalam mengelola industrinya. Sementara itu, ilmu-ilmu humaniora terpinggirkan karena ilmu-ilmu tersebut tidak terlibat secara langsung dalam proses produksi. Anggota masyarakat akan merasa bangga bila anaknya memasuki bidang-bidang Matematika-IPA (MIPA) atau keteknikan. Persepsi ini telah sedemikian mengakar kuat dalam pikiran masyarakat sehingga mereka yang menekuni ilmu-ilmu humaniora merasa minder karena dianggap sebagai anak yang tidak cerdas, dan bernasib sial. Oleh karena itu, di beberapa lembaga pendidikan kelas-kelas humaniora menjadi "keranjang sampah" bagi mereka yang dianggap tidak cerdas. Bidang ilmu humaniora menjadi pilihan terakhir dan banyak diantara penekunnya dihinggapi pesimisme masa depan. Mentalitas inferior (inferior complex) ini tidak bisa begitu saja dituduhkan sebagai bawaan kepada para penekun humaniora karena penyebab kondisi itu lebih banyak dibentuk oleh opini masyarakat (Hadi and Nurhayati 2002, 279-280). 
Ketiga, pola pikir dan budaya Hedonisme dan materialistis. Di era globalisasi, pandangan dan pola pikir masyarakat lebih kepada kemajuan ekonomi. Liberalisasi ekonomi dan sistem kapitalis, mengizinkan setiap individu bebas untuk mendapatkan keuntungan dan berkompetisi untuk mencapai kemakmuran. Tidak ada larangan monopoli, persaingan yang keras saling menjatuhkan adalah hal yang biasa dan dianggap kompetisi yang dianggap sehat (fairplay). Sistem tersebut akan menimbulkan gap yang semakin curam antara si miskin dan si kaya; yang kaya semakin kuat dan yang miskin semakin terpinggirkan. Kaitan ekonomi dalam masyarakat cyber ini, logika partyline bukanlah logika aktivitas produktif melainkan kegiatan konsumtif (Indra 2005, 62-63). Consumerism harus dijaga dan dilindungi dari dominasi teknologi dan dunia usaha. Over consumption harus dijauhi karena akan berdampak negatif yang lebih luas. Perilaku yang konsumtif menimbulkan pendangkalan makna hidup, dekompensasi lingkungan, peperangan penyakit, kecelakaan, kepunahan hewan dan akhirnya kepunahan manusia sendiri (Jacob 1988, 17).

Keempat, komersialisasi Pendidikan. Pada hakikatnya, proses pendidikan membutuhkan pendanaan. Penggunaan dana tergantung pada sarana prasarana dan kualitas yang diharapkan dalam suatu proses pendidikan. Kualitas yang baik tentu saja membutuhkan pembiayaan atau pendanaan yang memadai. Hal demikian merupakan sesuatu yang wajar untuk dilakukan, tapi bukan bertujuan untuk mendapatkan profit baik untuk kepentingan kelompok atau pribadi. Terlebih lagi bertujuan untuk komersialisasi, ${ }^{*}$ sehingga orang tua banyak yang tidak sanggup,

* Komersialisasi berasal dari komersial adalah berhubungan dengan perniagaan/perdagangan, atau sesuatu untuk diperjualbelikan, atau sesuatu yang bernilai niaga tinggi, yang terkadang mengorbankan nilai sosial, budaya dan sebagainya. Komersialisasi berarti mengkomersialkan, yaitu perbuatan menjadikan sesuatu sebagai barang dagangan.Istilah komersialisasi sangat populer dan sangat relevan dalam dunia ekonomi yang berkaitan dengan sesuatu yang diperjualbelikan baik sumber daya alami, sumber daya hayati dan sumber daya nabati. Komersialisasi tidak relevan jika terjadi pada bidang pendidikan, karena pendidikan berkaitan dengan 
mengeluh karena tidak mendapat kesempatan untuk melanjutkan sekolah anaknya ke jenjang yang lebih tinggi karena biaya sekolah yang begitu mahal. Dampak dari semua ini menyebabkan terjadinya diskriminasi pendidikan yakni klasifikasi lembaga pendidikan (sekolah/perguruan tinggi) yang bonafide, butuh dana besar dan mahal dan lembaga pendidikan yang butuh dana murah. Mutu lembaga pendidikan tidak lagi dinilai dari segi kualitas akan tetapi dari segi kuantitas.

Arnold Toynbee, seorang ahli sejarah dan Filosof Inggris dalam karyanya Civilization on Trial or Challenge and Response, mengatakan bahwa naik turunnya peradaban dalam sejarah, disebut dengan istilah "tantangan dan respon". Tantangan terdiri dari masalah besar yang tidak terpecahkan dalam waktu dan tempat. Sedangkan respon atau jawabannya terletak pada generasi berikutnya baik bersifat positif, negatif atau pasif. Keprihatinan Toynbee tentang kenyataan bahwa kemajuan teknologi modern atau "peradaban modern" tidak mengubah kehidupan manusia menjadi lebih baik secara material, akan tetapi menimbulkan ketidak-adilan sosial dalam distribusi kekayaan yang diciptakan oleh inovasi teknologi (Rugina1998, 663).

Johannes Oentoro (Rektor Universitas Pelita Harapan) pernah menyinggung tentang pergeseran makna pendidikan dalam perkembangan ilmu pengetahuan dan teknologi abad XX. Paradigma modern mengharuskan manusia terampil, profesional dan modal suatu keniscayaan. Karenanya, paradigma lama yang memandang pendidikan sebagai proses idealisme dan kegiatan filantropisme dan bertujuan "memanusiakan manusia" mengalami kekaburan karena fenomena genetic manipulation (manipulasi gen), cyborg (Cybernatic Organism), automation (otomatis) dan robotics (robotik). Pertanyaan yang krusial adalah apakah hasil proses pemanusiaan itu "human being atau technobeing"? (Oentoro 2004, 6-8).

Dengan meminjam istilah Johannes Oentoro "human being

pengembangan sumber daya manusia yang notabenenya sebagai pelaku ekonomi (Rustiawan 2015, 54). 
atau technobeing" maka praktik-praktik komersialisasi pendidikan seperti di atas menurunkan kualitas pendidikan dan harapan untuk melahirkan generasi-generasi bangsa yang berkualitas atau "memanusiakan manusia" yang sesuai dengan tujuan Pendidikan Nasional Indonesia sulit tercapai. Oleh karena itu kita membutuhkan penaksiran pembiayaan yang seimbang dengan kebutuhan-kebutuhan suatu sekolah atau perguruan tinggi, dan bukan untuk komersialisasi.

Memang, regulasi pembiayaan/pendanaan tidak ada yang sama pada semua instansi pendidikan, begitu juga implementasinya. Meskipun sudah ada aturan yang jelas, akan tetapi masih terdapat gap dalam pelaksanaannya. Kondisi ini tentu saja tidak terlepas dari kondisi ekonomi, komitmen, political will yang kadang-kadang tidak sepadan. Untuk Indonesia, jika merujuk pada UUD 1945, seharusnya biaya pendidikan menjadi tanggungjawab pemerintah bukan tanggungjawab individu karena setiap tahun membayar pajak yang tujuannya untuk pembangunan dan kesejahteraan warga negara Indonesia (Rustiawan 2015, 23). Praktik-praktik komersialisasi tidak sesuai untuk pendidikan karena pendidikan bukan untuk diperjual belikan, dan hal ini sangat bertentangan dengan nilai etika, agama dan budaya. Praktik ini juga merupakan salah bentuk korupsi yang akan mewarisi sifat-sifat negatif pada generasi bangsa dan mengaburkan nilai humanisme pada proses pendidikan, yang seharusnya dipertahankan dan ditingkatkan.

Kelima, memudarnya kebersamaan, lebih berorientasi individualistic personality. Akulturasi budaya dan kemunculan budaya negatif tidak dapat dielakkan. Seperti budaya kekejaman, kekerasan baik fisik maupun psikis semakin meningkat dan bahkan menjadi sebuah kepuasan. Perasaan bersalah, berdosa dan hina tidak lagi dirasakan, tetapi justru sebaliknya memunculkan perasaan kejantanan, kemenangan dan kebanggaan (Indra 2005, 131).

West mengingatkan bahwa kekejaman manusia (human brutality) di penghujung abad 20 ini tidak terlepas dari pengaruh 
kekejaman Nazi yang telah mendominasi Eropa. Stalinisme telah menjadi inti dari gerakan emansipasi Uni Soviet. Kolonialisme dan imperialisme Eropa di Afrika, Amerika Serikat dan Asia telah meninggalkan luka-luka yang tidak berkesudahan bagi umat manusia (Koesoema 2007, 117). Rasa sosial dan gotong royong mengalami pemudaran dan berkurang di masyarakat. Masing-masing sibuk berkompetisi pada kegiatan-kegiatan yang mendatangkan keuntungan dan ekonomi yang banyak. Pada hakikatnya gotong royong masyarakat sangat penting karena dahulu dalam menegakkan negara Indonesia dilakukan dengan gotong royong. Tapi berbeda dengan sekarang, gotong royong dilakukan sekelompok orang yang menginginkan kepuasan yang bersifat individual dengan cara menguras sumber daya alam dan membuat hutang ke luar negeri (Indra 2005, 132). Sikap individualitas dan hanya mengutamakan kepentingan pribadi bukanlah ciri dari kepribadian bangsa Indonesia dan hal ini sangat bertentangan dengan Pancasila sila ke 3.

Keenam, memperburuk kualitas Sumber Daya Manusia (SDM) dan kepemimpinan masa depan. Hal ini didorong oleh sifat dan tujuan manusia untuk mengumpulkan atau mengakumulasikan kapital sebanyak-banyaknya. Lembaga Pendidikan kehilangan budaya akademik menjadi budaya ekonomis. Lembaga pendidikan lebih mengutamakan menerima calon siswa yang lebih kaya walaupun IQ nya pas-pasan, dan siswa yang memiliki IQ yang tinggi terpinggirkan karena miskin dan tidak memiliki uang yang cukup untuk melanjutkan pendidikan lebih tinggi. Para guru dan calon sarjana memiliki mental pedagang ketimbang mental pendidik dan profesional. Hal ini tentu saja mereduksi fungsi pendidikan sebagai pemberdayaan kemajuan dan mencerdaskan kehidupan bangsa bergeser pada privatisasi pendidikan pada pelanggengan poverty trap. (jebakan kemiskinan) (Machali 2004, 127-128).

Melihat dampak globalisasi terhadap proses pendidikan saat ini, maka perlu reorientasi pendidikan ke depan sebagai tombak kemajuan mencerdaskan kehidupan bangsa. Globalisasi bukanlah suatu hal yang dijauhi, akan tetapi perlu diikuti dengan 
kesiapan mental dan daya nalar yang kritis, humanis dan agamis, sehingga pendidikan mampu melahirkan output-output yang cerdas secara intelektual, personal, sosial dan kinestesis vokasional.

\section{E. Dialektika Sains dan Agama Sebagai Solusi}

Globalisasi seperti dua sisi mata uang. Di satu sisi, era industri dan globalisasi menimbulkan gaya hidup global dan kebebasan lahiriah. Kebebasan ini melahirkan penyakit sosial, egoisme, hedonisme dan materialisme, perilaku sex bebas, narkoba, kebebasan mendapatkan keuntungan dan perekonomian dengan berbagai cara dan sebagainya. Hal ini terjadi pada masyarakat yang belum memiliki kesiapan mental dalam menghadapi era ini. Di sisi lain, globalisasi juga memberi dampak positif dan menjadi tantangan bagi bangsa Indonesia untuk mampu mencernanya, selama tidak bertentangan dengan nilai budaya lokal, nasional terutama agama. Nilai-nilai positif dari dunia Barat bisa diadopsi, misalnya budaya disiplin, kebersihan, tanggungjawab, egalitarianisme, kompetisi, kerja keras, penghargaan terhadap waktu, demokrasi dan semacamnya. Di sinilah peran agama sangat diperlukan dalam mengiringi kemajuan pengetahuan dan teknologi, sehingga menciptakan bangsa yang bermoral, bermartabat dan berkemajuan (Indra 2005, 77).

Arus globalisasi yang ditandai dengan perkembangan pengetahuan dan teknologi secara masif ini tentu saja akan mempengaruhi proses pendidikan yang dilaksanakan di lembaga pendidikan. Menggunakan strategi tunggal saja tidak cukup untuk melahirkan para lulusan yang berkualiatas secara akademik dan moral. Artinya diperlukan multi pendekatan yang oleh Kirschenbaum menyebutnya pendekatan komprehensif. Yakni proses pendidikan yang melibatkan orang tua, pendidik dan pemuka masyarakat yang mampu bersatu padu melibatkan diri dalam memberikan pendidikan nilai dan moralitas kepada generasi muda (Zuchdi 2009, 36).

Terrel H. Bell mengungkapkan sistem pendidikan yang baik 
sebagai berikut:

If the educational system works...it provides students the skill and desire to learn and to keep on learning through life. It prepares them for a rewarding career in a filed of their choice. It gives them the ability to make wise decision about their personal life and to participate responsibily in the democratice processes of our society. Most of all and I think this is too often overlooked education should teach young people how to enjoy life, how to get a kick out of it. Life is a great experience if you're trained and confidence qnd kmow where you're going. An education that meets all requirement is by far the greatest gift that Amerika can bestrow upon its young people (Zuchdi 2009, 37).

Menurut Terrel Bell, Sistem pendidikan yang baik harus berfungsi memberikan siswa keterampilan dan keinginan untuk belajar dan terus belajar sepanjang hidup; mempersiapkan mereka untuk berkarier, kemampuan untuk membuat keputusan bijak tentang kehidupan pribadi mereka dan untuk berpartisipasi secara bertanggung jawab dalam proses demokrasi masyarakat. Hidup adalah pengalaman hebat jika terlatih dan percaya diri dan mengetahui tujuan hidup. Pendidikan yang memenuhi semua persyaratan ini merupakan hadiah terbesar yang telah diberikan oleh Amerika kepada generasinya.

Artinya, Fungsi sosial lembaga pendidikan seharusnya tidak hanya memberikan kesempatan kepada subjek didik untuk mengembangkan pengetahuan. Fungsi penting lainnya ialah menciptakan setting sosial yang memungkinkan implementasi pengetahuan sebagai problem solving yang diperoleh untuk memecahkan masalah terhadap problema yang ada di masyarakat. Oleh karena itu pendidikan harus mampu menjadi pendidikan yang ideal bagi masyarakat. Pendidikan tanpa nilai-nilai sosial tidak akan efektif (Zuchdi 2009, 6). Sekolah sebagai lembaga pendidikan formal seharusnya menjalankan proses pendidikan yang memiliki sifat bidireksional, yaitu pengembangan kemapuan intelektual dan kemampuan moral. Dua arah pengembangan 
ini menjadi idealisme bagi siswa agar mereka semakin mampu mengembangan ketajaman intelektual dan integritas diri yang berkarakter (Koesoema 2007, 115).

Untuk mewujudkan keinginan dan harapan pendidikan yang ideal, perlu pembaharuan kurikulum pendidikan, yang bercirikan: 1) mampu menumbuhkan kesadaran kolektif peningkatan martabat kemanusiaan dan individu sebagai pribadi. Tanpa jiwa ini, pendidikan hanya untuk orang yang memiliki kekayaan sedangkan mereka yang miskin akan tambah tak berdaya dan terpinggirkan di era globalisasi. 2) berperan dalam pembentukan individu sebagai makhluk sosial artinya pengembangan kesadaran akan hak-hak dan kehidupan bersama realisasi tanggung jawabnya sebagai anggota masyarakat. Dan 3) kurikulum mampu mengembangkan kemampuan intelektual, kreatifitas dan kompetisi yang utuh baik moral maupun kapasitas keilmuan dan teknologi (Koesoema 2007, 267).

Untuk mencapai tujuan pendidikan ideal yang mengembangkan potensi peserta didik agar menjadi manusia yang beriman dan bertakwa kepada Tuhan Yang Maha Esa, berakhlak mulia sehat, berilmu, cakap kreatif, mandiri dan menjadi warga negara yang demokratis serta bertanggung jawab, maka tidak terlepas dari perangkat mata pelajaran atau program pendidikan pada suatu lembaga pendidikan yang disebut kurikulum. Sebagaimana dijelaskan di atas, kurikulum harus terintegrasi antara sains (ilmu pengetahuan dan teknologi) dan agama. Sifat kritis dan ilmiah sains terhadap realitas sangatlah berguna untuk mengelupaskan sisi-sisi "ilusif" agama, menghindari sifat stagnasi dan sebagai pengukuh dan penguat agama bagi pemeluknya karena sains mampu mengungkapkan rahasia-rahasia alam, bukan sebaliknya. Sedangkan agama bisa menjaga sikap mental manusia agar tidak mudah terjerumus ke dalam mentalitas pragmatis-instrumental, yang menganggap bahwa sesuatu dianggap bernilai sejauh ada manfaatnya dan bisa digunakan untuk kepentingan (Bagir 2005, 47).

Muzaffar Iqbal menyebutkan bahwa pertumbuhan dan 
perkembangan sains dalam Islam diinspirasi oleh petunjuk-petunjuk al-Qur'an. Bahkan matematika dan astronomi sangat berkaitan teori kosmologi dalam al-Qur'an atau teori ' $h a y^{\prime} a$ ' (Iqbal 2007, 10). Al-Qur'an memang bukan kitab matematika, astronomi ataupun pengobatan, akan tetapi ayat-ayat di dalamnya menginspirasi para saintis untuk membuktikan dan melahirkan inspirasi sains yang terdapat di dalamnya (Abdul-Rahman 2003, 24).

Dengan demikian dapat disimpulkan bahwa agama dan sains pada hakikatnya merupakan kebutuhan asasi (pokok) bagi umat manusia. Oleh karenanya, jadilah manusia agamawan yang saintis, atau saintis yang agamawan, sebagaimana yang diungkapkan oleh Albert Einstein bahwa "Religion without science is blind: science without religion is lame". Agama akan buta tanpa sains,dan sains akan lumpuh tanpa agama. Berangkat dari ungkapan di atas, bahwa agama dan sains bukan berjalan linear dan terpisah akan tetapi perlu seiring untuk mencapai peradaban dunia yang produktif, humanis, bermoral dan bermartabat.

Sebuah tawaran penulis, reformasi pendidikan suatu keharusan dan kebutuhan dalam menghadapi perkembangan industri dan teknologi di era globalisasi ini, dengan berpijak pada empat hal: (1) value approach. Artinya pendidikan harus menginternalisasikan nilai-nilai agama dan budaya dalam prosesnya, sehingga siswa memiliki kepribadian yang holistik. (2) social cultural approach, artinya pendidikan harus mengembangkan nilai-nilai sosial dan budaya, seperti rasa kepedulian, saling menghargai, tenggang rasa sesama dan tanggung jawab pada diri anak didik. (3) Cognitive and skill approach, artinya pendidikan harus mengembangkan daya nalar dan pikir yang progresif, dan keahlian teknis dalam menggunakan teknologi dan 4) Political policy approach, artinya kebijakan politik pendidikan harus menjunjung tinggi nilai kemanusiaan, keadilan, kecerdasan dan kesejahteraan bangsa. 


\section{F. Catatan Penutup}

Globalisasi bisa menjadi peluang (opportunity) di satu sisi, dan menjadi ancaman (threat) bagi pendidikan saat ini. Pendidikan merupakan investasi suatu bangsa untuk menciptakan manusia yang berkualitas, berilmu dan bermartabat. Prinsip-prinsip dasar pendidikan sebagaimana yang diamanatkan oleh Undang-Undang Pendidikan tidak akan mampu terealisasikan jika proses pendidikan hanya berorientasi pada tindakan pengkultusan teknologi sebagai satu-satunya sumber kemakmuran dan kemajuan (technocentrism), karena hal itu akan memunculkan masyarakat yang konsumtif, hedonis dan materialistis dan melunturkan sisi kemanusiaan manusia (dehumanism).

Solusinya, agama dan etika sangat diperlukan untuk mengimbangi perkembangan ilmu pengetahuan dan teknologi agar pendidikan dapat berperan untuk memanusiakan manusia atau meminjam istilah Johannes Oentoro: pemanusiaan dalam arti "human being", dan bukan "technobeing", dengan reparadigmatisasi pendidikan dengan menggunakan value approach, social cultural approach, cognitif and skill approach dan politic policy approach, sehingga proses pendidikan mampu melahirkan output dan masyarakat yang berkualitas, profesional dan bermartabat.

\section{DAFTAR PUSTAKA}

Apple, Michael W., Jane Kenway and Micheal Sinh. 2005. Globalizing Education: Policies, Pedagogies \& Politics. New York: Peter Lang.

Al-Faruqi, Ismail Raji. 1988. Islamization of Knowledge: General Priciples and Workplan. Herndon, Virgina, US: International Institute of Islamic Thought.

Abdullah, Irwan. 2010. Konstruksi dan Reproduksi Kebudayaan. Yogyakarta: Pustaka Pelajar.

Brock Bastian, Brock and Nick Haslam. 2011. Experiencing Dehumanization: Cognitive and Emotional Effects of Everyday Dehumanization. Australia: PsychologyPress. 
Potret Pendidikan di Era Globalisasi

Baqir, Zainal Abidin. 2005. Integrasi Ilmu dan Agama Interpretasi dan Aksi. Bandung: Mizan.

Indra, Hasbi. 2005. Pendidikan Islam Melawan Globalisasi. Jakarta: Ridamulia.

Iqbal, Muzaffar. 2007. Science and Islam. New York: Greenwood Press.

Istiarsono, Zen. 2016. "Tantangan Pendidikan dalam Era Globalisasi: Kajian Teoritik." Jurnal Intelegensia 1 (2).

Koesoema, Doni. 2007. Pendidikan Karakter Strategi Mendidik Anak di Zaman Global. Jakarta: PT Grasindo.

Machali, Imam. Pendidikan Islam dan Tantangan Globalisasi, editor: Imam Machali dan Musthofa, (Yogyakarta: PRESMA Fak. Tarbiyah UIN Sunan Kalijaga, 2004)

Oentoro, Johannes. 2004. "Industrialisasi atau Komersialisasi Pendidikan". Kompas. 6 September 2004.

Rahman, Muhammad Saed Abdul. 2003. Islam: Questions and Answers, The Qur'an and its Sciences. London: MSA Publication Limited, 4 Bello Close.

Rugina, Anghel N. 1998. "Dehumanization of Modern Civilization and a New". Emeraldinsight Publication International Journal of Social Economics 25 (5): 663.

Rustiawan, Hafid. 2015. "Komersialisasi Pendidikan (Analisis Pembiayaan Pendidikan)." Jurnal Keislaman dan Kemasyarakatan Kebudayaan 16 (1).

Syaeful Hadi, Bambang dan Iffah Nurhayati. 2002. "Hegemoni Budaya Industri dalam Pendidikan Kontemporer." Jurnal Ilmiah Pendidikan 21 (3).

Solikhudin, Muhammad. 2016. "Rekonsiliasi Tradisi Muslim dan Sains Modern (Telaah atas buku Islam's Quantum Question karya Nidhal Guessoum)." Jurnal Kontemplasi 4 (2).

Suyanto dan M.S. Abbas. 2004. Wajah dan Dinamika Pendidikan Anak Bangsa. Yogyakarta: Adicita Karya Nusa.

T. Jacob. 1988. Manusia, Ilmu dan Teknologi. Yogyakarta: PT. Tiara Wacana. 
Eva Dewi

Yamin, Moh. 2009. Menggugat Pendidikan Indonesia. Yogyakarta: Ar-Ruzz Media.

Zuchdi, Darmiyati. 2009. Humanisasi Pendidikan. Jakarta: PT Bumi Aksara. 